\title{
Influence of Online Shopping Cart Abandonment: The Moderating Effect of Perceived Waiting Time
}

\author{
S.Arul Kumar, Krithika.M
}

\begin{abstract}
Purpose -This research explores the moderating impact of perceived waiting time with regard to the hedonic motivation and utilitarian motivation of the discarding online shopping cart without making any purchase.

Research design, data, and methodology - The data was collected from the study respondents through online structured questionnaire. The study used the Hayes process to analyse the influence of perceived waiting time concerning online shopping cart abandonment.

Results - This study demonstrates the most important association between hedonic motivation, utilitarian motivation and the rate of online shopping cart dropout.

Conclusions- Results from this study reveals that the perceived waiting time between hedonic motivation, utilitarian motivation and frequency of cart abandonment has a moderating impact. The hedonic shoppers will not wait for registration and page uploads, even if they search online portals for entertainment purposes.
\end{abstract}

Keywords: Online Shopping, Shopping cart abandonment, Online Behaviour, perceived waiting time, Hedonic motives, Utilitarian motives.

\section{INTRODUCTION}

The Internet is playing a vital role in today's business world. It has generated a huge volume of international business transactions. Not only does the Internet introduce a new way of doing business, it also transforms the lifestyle of customers. By going to a physical store, customers can purchase products or services over the Internet. Hence, researching this trend is very important, trying to ascertain the variables that ultimately inspire consumers to accept internet shopping. (Arulkumar, S., \& Kannaiah, D. 2015)

The shopping cart fall is when a potential customer starts an online order checkout process but exits the process before the transaction is completed. Every product entering the purchasing cart but never being transacted is deemed to be "abandoned" by the purchaser. The abandonment of the cart is an essential part of the online shopping process, which distributors take care of.

The abandonment rate of online shopping cart is calculated by dividing the total number of transactions completed into a total number of transactions initiated. The level would determine how much users wish to buy by adding a product to the cart, but not completing the

Revised Manuscript Received on 14, October 2019.

Dr.S.Arul Kumar, Associate Professor \& Dy.Coordinator, Department of Business Administration, Directorate of Distance Education, Annamalai University. Chidambaram, Tamilnadu, India.(E-mail: arulmba123@gmail.com)

Dr.Krithika.M, Assistant Professor, Saveetha School of Engineering, Saveetha University, Chennai, Tamilnadu, India.(E-mail: krithikam.sse@saveetha.com) transaction. In e-commerce sites, the shopping cart abandonment rate is significant because a high drop-off rate can signal poor user experience or break-down sales funnel. Reducing the abandonment of shopping carts would directly increase revenue and profits. That way, most online retailers are concentrating on improving the check-out process.

The rate of abandonment of online shopping cart is quite alarming as more consumers move towards mobile shopping. The product can be browsed increasingly easily on mobile phones, but it's still difficult to enter all form fields in the check-in phase. This reduces adaptations and increases the complete cart abandonment rate. It is estimated that this year (2018) the global Online shopping cart abandonment rates are increased to $73.4 \%$, compared to about $71.1 \%$ in 2014 .

The reasons for giving up online shopping carts are multiple. Unforeseen shipping costs, formation of accounts, bad checkouts and also the duration of the delivery also lead to make a purchase making decision being dropped. This study was conducted in order to know the reason for shopping online and why the cart was discontinued.

The abandonment of online shopping carts in academics, in particular in the Indian context, is not much discussed. It is therefore seen in academic research as an important topic. During the final procedure of the online sales counter process online shopping cart abandonment occurs. This field of research is therefore very little in an academic environment, especially in the field of security and process issues. Closing Angeline and Kukkar Kinney (2010).

The previous study conducted by Daan Wildeboer (2014) revealed that it is very tough to predict the motives behind cart abandonment during the check-out stage. Even if it is part of the online buying behaviour of customers, it is an unknown topic in academic research. Therefore, the abandonment of online shopping carts is seen as the most relevant topic for research in the exploration of new theoretical models for the online consumer purchase behaviour. The present study has attempted to uncover the various factors for online shoppers abandon their shopping carts and also measured the moderated effect of the time waited leads to online shopping cart abandonment. This understanding will enable e-tailers to devise suitable strategies, reduce the incidence on online cart abandonment and thus increase their top line. 


\section{Proposed model for the study}

\section{Figure-1 Proposed Model}

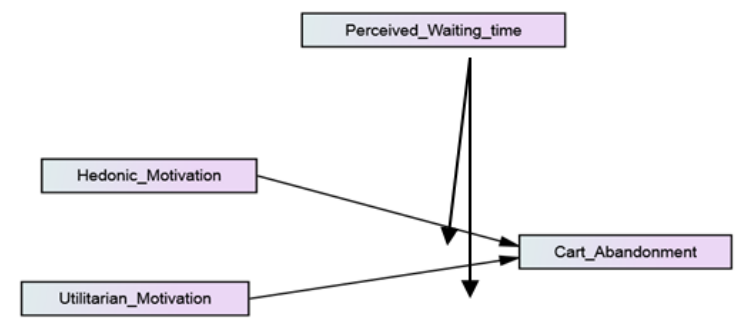

\section{RESEARCH OBJECTIVES}

* To explore the moderating impact of shopping motivations on cart abandonment

* To study the moderation effect of the perceived waiting time on the online shopping cart abandonment.

\section{REVIEW OF LITERATURE}

\section{Cart Abandonment}

In this study the term online cart abandonment as defined by Angeline Close "This cart abandonment behaviour is like placing items on the online cart without purchasing items at that shopping online session,". Study by Rajamma and.al (2009) states that cart abandonment was affected by the perceived waiting time, risk, and inconvenience of the transaction. In this study, the effect of perceived risk on the abandonment of shopping carts is investigated in addition to previous research projects.

\section{Perceived waiting time}

Perceived waiting Time to wait for getting a particular product or service. "The reaction of customers to waiting in line can change their view of the service delivery process," as said by Davis and Heineke (1998). The relationship between perceived waiting time and satisfaction is suggested by Maister, (1985); Davis and Vollmann, (1990); Davis and Heineke, (1998). Davis and Vollmann (1990) have declared that their customers are more impatient when there is limited time available. Authors Katz et al., (1991), and Pruyn and Smidts, (1998), indicated that basically customers exaggerate service waiting times. Reducing the duration of waiting time assume that saves more time for online customers.

According to a Neilsen,(1996) survey and study by Selvidge et al. in (2002) and Kuhnmann (1989), customers lost their interest in websites with a waiting time of more than 10 seconds. Selvidge et al. (2002) have observed that any barrier to waiting times is often frustrated when the online shopping cart is ultimately abandoned. Long waiting times in the transaction are therefore usually the order of purchase and the online shopping cart is dropped.

\section{Hedonic and utilitarian motives}

In order to further understand the perceived benefits of online and offline shopping, we need to take a deeper dive into what consumers value. Understanding consumer motivations and what drives them to shop online and/or in the traditional stores is key. The reasons to where and why we buy are linked to shopping values and motivations.

Wide-ranging evaluations of functional advantages and sacrifices are useful (Overby and Lee 2006). Utilities may also include intentional purchase at a particular online shopping session and financial incentives for money savings through online price promotions (e.g. Noble et al.'s, 2006; To et al., 2007). Similarly, utilities may be largely targeted and task-based for use with virtual carts, like adding a favourite products in the online cart for purchases, or saving their valuable time and money by shopping online, instead of traveling to a retail outlet to buy. Electronic shopping carts are useful because they are used as storage before, they are bought. However, their use also involves experiential hedonic aspects of shopping and purchasing online.

The shopper's assessment of the experience-based advantages and sacrifice defines hedonic shopping motivations, since consumers can take part in the experience of completing a task. The hedonic aspect of shopping therefore consists of fun and a pleasure of shopping (Babin et al., 1994). Different shopping types, including adventure shopping, gratification shopping, idea shopping and price shopping, are linked to hedonic motivations for online shopping (Arnold \& Reynolds, 2003). For example, as a form of entertainment, adventure shopping recognizes that shoppers seek sensory stimulation.

Liau and Lin (2007) studied shopping motivations on the Internet and identified four Utilitarian values that lead to Utilitarian motivation: cost saving, convenience, selection and information availability. They also found two hedonic values, adventure/explore and authority/status as predictors of hedonic motivation. In contrast to Arnold and Reynolds, they found no support for value, social and idea shopping as hedonic motives.

Rigby (2011) also identified these opportunities, as well as convenient and fast check-out, and the customers' ability to get anything, anytime, anywhere. Again, these are more Utilitarian values. Chen \& Lee (2008) found that consumers who perceive higher Utilitarian values in websites will have a higher level of trust in online shopping. This was not true for higher hedonic values. Online shopping tends to be less hedonic, as the online shopping experience is still far less exiting than its offline competition (Wolfinbarger and Gilly, 2001). Contrastingly, Childers et al. (2001) found that while Utilitarian motives are important predictors of online attitudes, the more immersive, hedonic aspects play at least an equal role. They argue that online retailers now have powerful new media at their disposal that can fulfil hedonic needs such as, images, videos, humor, sounds, animation, games and more interactive multimedia that can make online shopping an enjoyable experience.

\section{METHODOLOGY}

The study is descriptive in nature because study has attempted to uncover the various factors of online shoppers abandoning their shopping carts and also measured the moderated effect of the waiting time behind shopping cart 
abandonment. For investigating this study objectives, the questionnaire has been used as a suitable tool for primary data collection. This is because of intricate research area, hence questionnaire become natural way of gathering primary data. The data was collected through Internet as the study respondents might be very young and frequently use the internet and those who already have the history of abandoned the cart during the purchasing process. Items in the research instrument were developed on the basis of literature review. Questions listed in the questionnaire were pre-tested on a sample of 50 respondents. The pre-testing of questionnaire has helped in modifying some statements based on the changes sought by the respondents. The Corn Bach alpha method is used to identify reliability of the questionnaire. It reveals that $88.7 \%(\infty=0.88)$ of total variance is present for the statement in Likert five-point scale. Hence the reliability of the statement is significant. Content validity of the tool was confirmed by discussing with the experts. The final (modified) questionnaire after pre-testing was used for collecting the data. For the study stratified random sampling method has been used for collecting necessary primary data. A sample size of 389 respondents was selected and they have been requested to exhibit their responses. The structural equation modelling using AMOS 20 and Hayes process macro was used to study the objectives.

\section{ANALYSIS AND INTERPRETATION}

In the hypothesized model, Figure 4.1 exhibits the relationship between independent and dependent variables. Structural equation model was then run and found that the conceptual model was structurally and statistically identified.

Table - 1 Goodness of Fit Index

\begin{tabular}{|l|l|}
\hline X2/df & 4.108 \\
\hline RMSEA & .061 \\
\hline NFI & .780 \\
\hline CFI & .878 \\
\hline GFI & .925 \\
\hline AGFI & .812 \\
\hline
\end{tabular}

Table -2 SEM Model and Hypothesis Testing Results

\begin{tabular}{|l|l|l|l|l|l|l|l|}
\hline & & & Path Estimate & S.E. & C.R. & P & Hypothesis \\
\hline Cart Abandonment & $<---$ & Hedonic Motivation & -.036 & .007 & -5.004 & $* * *$ & Supported \\
\hline Cart Abandonment & $<---$ & Utilitarian Motivation & .057 & .023 & 2.451 & .014 & Supported \\
\hline
\end{tabular}

Table -3 Standardized Regression Weights

\begin{tabular}{|l|l|l|l|l|l|l|}
\hline & & & Estimate & Total.Effect & Direct.Eff & Indirect.eff \\
\hline Cart Abandonment & $<---$ & Hedonic Motivation & -.171 & -0.036 & -0.036 & 0.000 \\
\hline Cart Abandonment & $<---$ & Utilitarian Motivation & .084 & 0.057 & 0.057 & 0.000 \\
\hline
\end{tabular}

$H_{1}$ : Hedonic motivation affects the online shopping cart abandonment rate positively

The relationship between cart abandonment rate and hedonic motivation is explored in Hypothesis 1. The hedonic motive and rate of cart abandonment are believed to be in a positive relation. The results showed that this relationship has a total likelihood value of-0.036 and the standard error is 0.007 with a critical level value of 5.004. There was a big p-value. Consequently, the hypothesis (H1) is rejected. This indicates that an increase in the motivation of a hedonic group contributes to a decrease in the rate of online shopping cart drops. The standard weight of regression indicates the intensity of the correlation between the unobserved variables. Hedonic motivation is found to affect the rate of cart abandonment at 17.1 percent.

H2: Utilitarian Motivation has a positive impact on cart abandonment frequency

The relationship between utility motive and rate of cart abandonment was analysed in Hypothesis 2. It was believed that the useful motives would be associated positively with the cart withdrawal rate. The results showed that this correlation is calculated to be 0.057 with a critical ratio of 2.451. The standard error is 0.023 . There was a big p-value. The hypothesis (H2) is therefore appropriate. The rise of one unit of utilitarian incentive indicates that the rate of cart drop-off decreases by 0,084 . The value of standardized regression weight indicates the strength of the relationship between the variables which was not observed. Utilitarian motivation impacts the cart level at 8.4 per cent.

\section{Moderation 1:}

The aim of this study to analyse the influence of the perceived waiting time on hedonic motivation and cart abandonment. $\mathrm{M}$ is perceived waiting time, shown here to control the size of the effect of $\mathrm{X}$ - Hedonic motivation on $\mathrm{Y}$ Cart abandonment, which implies that the size of the effect of $\mathrm{X}$ on $\mathrm{Y}$ depends on $\mathrm{M}$. 


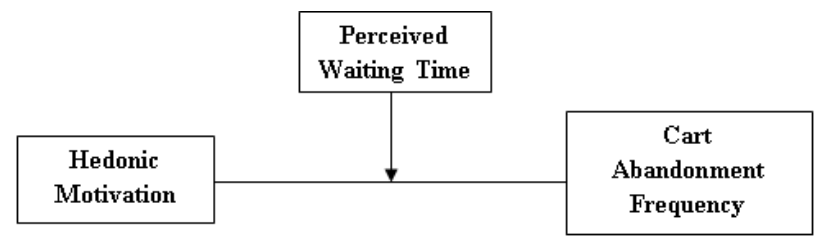

Figure -2. Moderation Effect of the Perceived waiting time on Hedonic motives and cart abandonment

H3: perceived waiting time is substantially moderating between hedonic motivation and rate of cart abandonment.

The following is Andrew F Hayes process summary

The author used the Model $=1$ to check the moderating effect. In that, the dependent variable

$\mathrm{Y}=$ Cart Abandonment Frequency, the independent variable $\mathrm{X}=$ Hedonic Motivation and the moderating variable $\mathrm{M}=$ perceived waiting time.

Table - 4. Model Summary

\begin{tabular}{|l|l|l|l|l|l|l|}
\hline R & $\begin{array}{l}\text { R- } \\
\text { Squar } \\
\text { e }\end{array}$ & MSE & F & df1 & df2 & p \\
\hline .1624 & .0254 & $\begin{array}{l}2.616 \\
6\end{array}$ & 9.2 & 3 & 814.0 & $.000^{*}$ \\
\hline
\end{tabular}

Source: Primary data* $1 \%$ level of significance

Table-5 Model

\begin{tabular}{|l|l|l|l|l|l|l|}
\hline & Coefficient & se & t & p & LLCI & ULCI \\
\hline Constant & 7.9012 & .0587 & 142.4203 & .000 & 7.825 & 8.0743 \\
\hline Perceived Waiting Time & -.0003 & .0085 & -.0257 & .961 & -.0196 & .0193 \\
\hline Hedonic Motivation & -.0320 & .0068 & -4.334 & .0000 & -.0448 & -.0175 \\
\hline Int_1 & -.0027 & .0013 & -2.1740 & .0272 & -.0045 & -.0012 \\
\hline
\end{tabular}

Source: Primary data* $1 \%$ level of significance

Interaction_1: Hedonic motivation X perceived waiting time

Table-6 R-square increases due to interaction(s)

\begin{tabular}{|l|l|l|l|l|l|}
\hline & $\begin{array}{l}\mathbf{R}^{2}- \\
\text { change }\end{array}$ & F & df1 & df2 & p \\
\hline $\begin{array}{l}\text { The interaction } \\
\text { of Hedonic } \\
\text { motivation X X } \\
\text { perceived } \\
\text { waiting time }\end{array}$ & & & & & \\
& & & & & \\
\hline
\end{tabular}

Source: Primary data* $1 \%$ level of significance

The study results show the performance of the Hayes process model -1 to see the moderating impact of perceived waiting time between hedonic motivation and rate of cart abandonment. Model 1 was used to check the impact of the moderating variable.

The overview analysis has shown that a significant statistical effect exists. As described below, the results can be concise.

$$
\mathrm{F}=4.7742, \mathrm{P}<0.05, \mathrm{R} 2=0.0054 \text {. }
$$

The regression table portrayed above shows the impact of the moderating variable on the outcome variable. The statistical results show that the $\mathrm{p}$ value is significant with a $\mathrm{p}$ value of 0.0292 , which is $>0.05$. The null assumption is therefore dismissed and the alternative hypothesis statement accepted. The positive interval (LLCI=-.0043 and ULCI=.0002 ) for the word interaction does not include 0 and therefore the population is slightly affected.

\section{Slope test}

The slope test displays the interactive relationship of perceived waiting time on the relationship between hedonic motivation and cart abandonment frequency. The results proved that there is an interaction effect between hedonic motivation and cart abandonment frequency is positive in both low level of waiting time as well as high level of perceived waiting time. The effect of hedonic motivation on cart abandonment frequency is much stronger among the low level of perceived waiting time. The above figure -2 depicts clearly the stronger relationship by the way of comparing the slope of low perceived waiting time and to the slope of high perceived waiting time.

\section{Moderation 2:}

Effect of perceived waiting time on Utilitarian Motivation and cart abandonment.

$\mathbf{M}$ is depicted here is the moderating variable perceived waiting time to moderate the size of the effect of the independent variable $\mathrm{X}$ - utilitarian motive on the dependent variable $\mathrm{Y}$ - Cart abandonment, meaning that the size of the effect of $\mathrm{X}$ on $\mathrm{Y}$ depends on $\mathrm{M}$. We say $\mathrm{M}$ is the moderator of the $\mathrm{X} \rightarrow \mathrm{Y}$ relationship, or $\mathrm{X}$ and $\mathrm{M}$ interact in their influence on $\mathrm{Y}$.

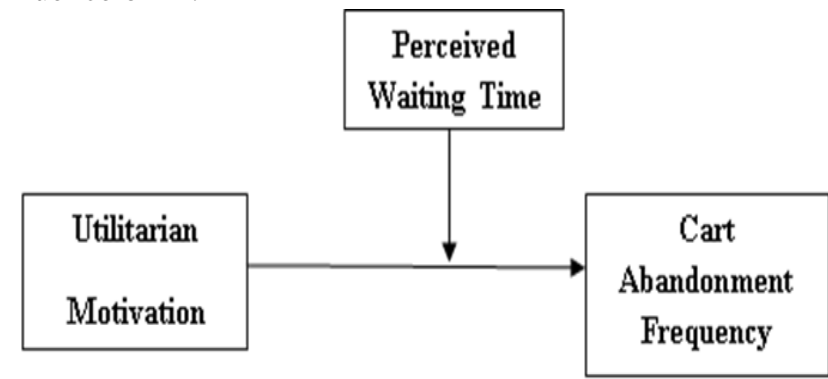

Figure-3 Moderating Effect of perceived waiting time on Utilitarian Motivation and cart abandonment Frequency

H4: There is a substantial moderating effect of perceived waiting time on Utilitarian motivation and cart abandonment frequency.

Andrew $F$ Hayes process was used to analyse. The Model $=1$ was chosen to perform the moderation analysis, where the dependent variable $\mathrm{Y}=$ Cart Abandonment Frequency and the independent variable $\mathrm{X}=$ Utilitarian Motivation and the moderating variable $\mathrm{M}=$ perceived waiting time were assigned to run the process matrix model1.

\section{Table-7 Model Summary}

\begin{tabular}{|c|c|c|c|c|c|c|}
\hline $\mathbf{R}$ & \begin{tabular}{|c|} 
R- \\
square
\end{tabular} & $\mathbf{E}^{\mathbf{M S}}$ & $\mathbf{F}$ & df1 & df2 & $\mathbf{p}$ \\
\hline .091 & .0092 & $62^{2.61}$ & $81^{2.84}$ & 3 & $\begin{array}{l}814.0 \\
000\end{array}$ & 2.036 \\
\hline
\end{tabular}

Source: Primary data* $1 \%$ level of significance 
Table-8 Model

\begin{tabular}{|l|l|l|l|l|l|l|}
\hline & Coefficient & $\mathbf{s}$ & $\mathbf{t}$ & $\mathbf{p}$ & LLCI & ULCI \\
\hline Constant & 7.9241 & .0523 & 136.0785 & .0000 & 7.8024 & 8.0762 \\
\hline Perceived Waiting Time & -.0043 & .0091 & -.4325 & $.6017^{*}$ & -.0260 & .0119 \\
\hline Utilitarian Motivation & .0341 & .0214 & 1.6620 & $.1028^{*}$ & -.0075 & .0821 \\
\hline Int_1 & .0071 & .0032 & 2.5134 & $.0091^{*}$ & .0021 & .0132 \\
\hline
\end{tabular}

Source: Primary data* $1 \%$ level of significance

Interaction effect_1: Utilitarian motivation $\mathrm{X}$ perceived waiting time

Table- 9 R-square increase due to interaction(s)

\begin{tabular}{|c|c|c|c|c|c|c|}
\hline & & $R^{2}$-change & $\mathbf{F}$ & df1 & df2 & $\mathbf{p}$ \\
\hline \begin{tabular}{|ll} 
Interaction & of \\
motivation & $X$ \\
waiting time &
\end{tabular} & $\begin{array}{r}\text { Utilitarian } \\
\text { perceived }\end{array}$ & .0083 & 6.8456 & 1.0000 & 824.0000 & $.0090 *$ \\
\hline
\end{tabular}

Source: Primary data* $1 \%$ level of significance.

The above table depicts the findings of the Hayes process matrix outcome to find out how the perceived time influencing between utilitarian motivation and the level of cart abandonment. Hayes Model 1 was used for running the moderation analysis.

The overview model shows that the moderating effect is important. As described below, the results can be concise.

$\mathrm{F}=6.8456, \mathrm{P}<0.01, \mathrm{R} 2=0.0083$. of moderating variable on the outcome variable. The results show that $\mathrm{p}$ values are not statistically significant, with $\mathrm{p}$ as 0,0090 , which is $<0,05$. According to statistics. The null hypothesis is therefore dismissed and the alternative hypothesis is accepted.

The upper limit and the lower limit interval for this time (LLCI=.0020 and ULCI=.0142) does not include zero, and therefore the population has a moderating effect.

\section{Slope Test}

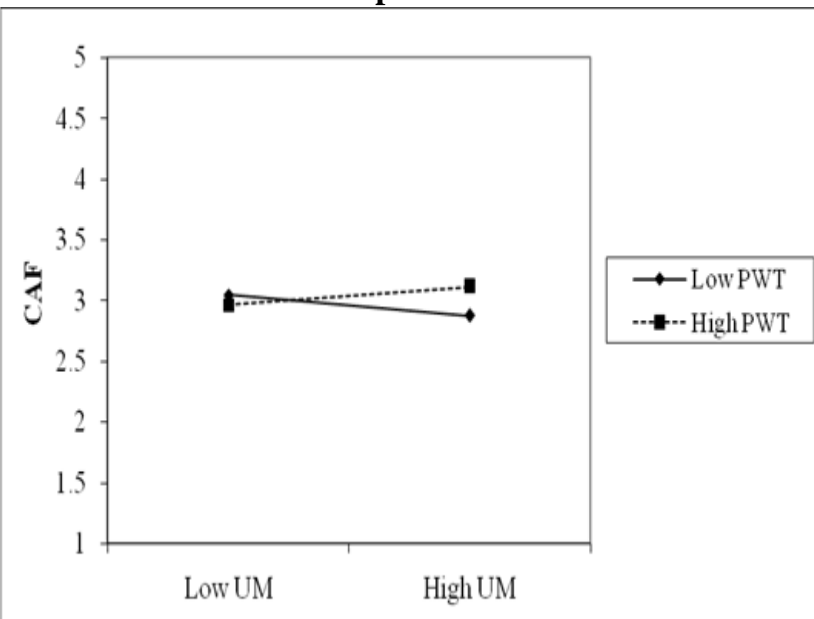

Figure- 4 The Effect of interaction between Utilitarian Motivation and perceived waiting time on cart abandonment Frequency

The above slope test shows the relationship between perceived waiting time and utilitarian motivation on the rate of cart abandonment. In low level and high level of waiting time, the interaction impact of Utilitarianism motivation on the rate of cart abandonment is positive.

In the low level of perceived waiting time, the effect of Utilitarian motivation is stronger towards cart abandonment rate. The figure above shows clearly the stronger relationship, by contrasting and declining from a low time of wait and the pitch of a strongly perceived time of waiting.
The above moderation regression table shows the impact

\section{FINDINGS}

This study proposes a significant connection between the rate of cart abandonment and hedonic motives. In previous studies, it is clear that hedonic value-led online shoppers rather than product-buying mostly left their items in their online shopping cart. Kukar-Kinney and Close (2010) proposed the hypothesis that the more digital carts are used by buyers, the more likely the online purchase cart will be abandoned. This hypothesis is reinforced strongly by this research and is part of the Daan Wildeboer study (2014) because the consumer behaviour seeks to create a dream wish list and considers shopping a stimulant reality.

It was found that there were no statistically significant research findings on the relation between utilitarian motif and cart drop-out rate. The Krithika. M and G.Rajini (2017) shows that utilitarian motivation affects adversely on the cart abandonment rate.

The aim is not for customers to leave their favourite products in the online shopping cart. We also endorse Daan Wildeboer (2014) and KrithikaM.and G. Rajini (2017).

\section{DISCUSSION \& RESULTS}

Their results show that between hedonic intent and the rate of abandonment of the vehicle, a moderating effect is perceived. Even if the hedonic clients search online shopping portals for the purpose of entertainment, they are not willing to wait for long time to complete the registration process and upload in the site for a long time. Childers et al. 2001; Wolfinbarger and Gilly, 2001; Balabanis and Vassileiou, 1999 indicate that the concept of waiting, as online shops wishing to save time, is the most important factorHence the customers ' expectations may not be verified in any lag in completing their purchases online, such as slow page loading, anticipating upload and long registration form. This leads to unhappiness and the shopping cart is lost. Thereby, in the final check-out cycle, we find that longer waiting time contributes to the termination of the online cart purchase and abandonment. This study results are same as the study of Rajasree K. Rajamma Audhesh K. Paswan and Muhammad M. Hossain, (2009).

The results of the second moderating effect between utilitarian motivation and the cart abandonment frequency shows the existence of the moderating effect.

The registration process is too long and the technical failures on the online portals made the payment process very hard, as customers felt that they had to wait for a period to be submitted to the website. This study aims to figure out the mysterious part of both academic and non-academic literature.

\section{LIMITATIONS AND DIRECTIONS FOR FURTHER RESEARCH}

1. The purpose of this research is to analyse the moderating effect of perceived waiting time on shopping motivations and cart abandonment. In future, the researchers 


\section{INFLUENCE OF ONLINE SHOPPING CART ABANDONMENT: THE MODERATING EFFECT OF PERCEIVED WAITING TIME}

may investigate the shopping cart abandonment by using more factors.

2. The study population is the online shoppers' in Chennai city; future studies can explore other populations across countries and contexts.

3. The present study measured cart abandonment rates during the purchase process of the following products namely, Kindle E-Reader \& E-Books Movies, Music, \& Video Games, Mobiles \& Tablets, Computers etc,. In future, study should be carried out about the cart abandonment among different product categories.

4. Web irritation, anxiety is important variables affecting cart abandonment. Other possible avenues for future research could be explore in the cart abandonment context.

\section{VIII.CONCLUSIONS}

This research work offers insights into the idea of shopping cart abandonment, focusing on the understanding of the consumer, as most studies develop around online shopping features such as online shopping acceptance, behaviour, and perceived ease of use.

Research's main goal is to find out how shopping motivations, namely hedonic and utilitarian, can impact cart abandonment as well as to find out the moderate effect of perceived waiting time on shopping motivations and cart abandonment. From the analysis, it is inferred that the most important factors to consider when discussing cart abandonment are utilitarian motivation.

It is concluded that there is a negative correlation between hedonic motivation and cart abandonment. This shows, however, that users with a hedonic mentality would show more browsing behaviour than their inspired counterparts in the Utilitarian. The main question discussed in this study was whether hedonic shoppers were more likely than utilitarian shoppers to give up their online shopping cart during the pre-check-out phases. The results obtained in the analysis validated this query. Utilitarian encouragement with cart abandonment showed positive influence.

This reinforces the hypothesis that consumers showing goal-driven click-stream trends are more likely to end their shopping session with a purchase. The results of this study clearly indicate that in order to reduce shopping cart abandonment rates, marketers must try to make the checkout process as simple as possible.

\section{REFERENCES}

1 Arulkumar, S., \& Kannaiah, D. (2015). Predicting purchase intention of online consumers using discriminant analysis approach. European Journal of Business and Management, 7(4).

2 Arnold, M. J., \& Reynolds, K. E. (2003). Hedonic shopping motivations. Journal of retailing, 79(2), 77-95.

3 Balabanis, G., \& Vassileiou, S. (1999). Some attitudinal predictors of home-shopping through the Internet. Journal of Marketing management, 15(5), 361385 .

4 Babin, B. J., Darden, W. R., \& Griffin, M. (1994). Work and/or fun: measuring hedonic and Utilitarian shopping value. Journal of consumer research, 20(4), 644-656.

5 Childers, J. B., \& Tomasello, M. (2001). The role of pronouns in young children's acquisition of the English transitive psychology, 37(6), 739.
6 Close, A. G., \& Kukar-Kinney, M. (2010). Beyond buying: Motivations behind consumers' online shopping cart use. Journal of Business Research, 63(9), 986-992.

7 Davis, M. M., \& Heineke, J. (1998). How disconfirmation, perception and actual waiting times impact customer satisfaction. international Journal of Service industry Management, 9(1), 64-73.

8 Davis, M. M., \& Vollmann, T. E. (1990). A framework for relating waiting time and customer satisfaction in a service operation. Journal of Services Marketing, 4(1), 61-69.

9 Davis, M. M., \& Heineke, J. (1998). How disconfirmation, perception and actual waiting times impact customer satisfaction. international Journal of Service industry Management, 9(1), 64-73.

10 Maister, D. (1985). The one-firm firm. Sloan Management Review, 27(1), 3-13.

11 Kuhlmann-Wilsdorf, D. (1989). Theory of plastic deformation:-properties of low energy dislocation structures. Materials Science and Engineering: A, 113, 141.

12 Overby, J. W., \& Lee, E. J. (2006). The effects of Utilitarian and hedonic online shopping value on consumer preference and intentions. Journal of Business research, 59(10), 1160-1166.

13 Pruyn, A., \& Smidts, A. (1998). Effects of waiting on the satisfaction with the service: Beyond objective time measures. International journal of research in marketing, 15(4), 321-334.

14 Rigby, D., \& Bilodeau, B. (2011). Management tools \& trends 2011. London: Bain \& Company.

15 Rajamma, R., Ball, R. J., Tarelho, L. A., Allen, G. C., Labrincha, J. A., \& Ferreira, V. M. (2009). Characterisation and use of biomass fly ash in cementbased materials. Journal of hazardous materials, 172(2), 1049-1060

16 Rajini, G., \& Krithika, M. (2017). Risk Factors Discriminating Online Metropolitan Women Shoppers: A Behavioural Analysis. International Journal of Cyber Behaviour, Psychology and Learning (IJCBPL), 7(1), 5264.

17 Selvidge, P. R., Chaparro, B. S., \& Bender, G. T. (2002). The world wide wait: effects of delays on user performance. International Journal of Industrial Ergonomics, 29(1), 15-20.

18 Su, K. P., Chiu, T. H., Huang, C. L., Ho, M., Lee, C. C., Wu, P. L.,... \& Pariante, C. M. (2007). Different cutoff points for different trimesters? The use of Edinburgh Postnatal Depression Scale and Beck Depression Inventory to screen for depression in pregnant Taiwanese women. General Hospital Psychiatry, 29(5), 436-441.

19 Tielsch, J. M., Sommer, A., Katz, J., Royall, R. M., Quigley, H. A., \& Javitt, J. (1991). Racial variations in the prevalence of primary open-angle glaucoma: the Baltimore Eye Survey. Jama, 266(3), 369-374.

20 Wolfinbarger, M., \& Gilly, M. C. (2001). Shopping online for freedom, control, and fun. California Management Review, 43(2), 34-55.

21 Wildeboer, D., \& Donkers, S. (2014). The Consumers Behind Online.

22 Wolfinbarger, M., \& Gilly, M. C. (2001). Shopping online for freedom, control, and fun. California Management Review, 43(2), 34-55. 